Dialectologia 25 (2020), 115-139.

ISSN: 2013-2247

Received 13 September 2018.

Accepted 21 November 2018.

\title{
REDUPLICATION INITIATED THROUGH DISCOURSE MARKERS: A CASE OF HADOTI
}

\author{
Gulab CHAND \& Somdev KAR \\ Amity University Gurgaon * Indian Institute of Technology Ropar * \\ potter.linguistics@gmail.com / somdev.kar@iitrpr.ac.in
}

\begin{abstract}
Reduplication is a common morphological process in many languages, particularly in South Asia. This study focuses on the reduplication phenomenon in Hadoti, where it ensues with the help of a discourse marker /rə/, functioning as an emphasizing agent in the process. This marker comes between the base and the reduplicant for expressing emphasis in work or action or verb (as in / $k^{\text {ha }}$ ra $k^{h} a /$ 'do eat,' etc.). In Hadoti, /rə/ functions as a vocative case marker when it comes at the end of the sentence as in /ram gjo rə/ 'Ram went'. However, when /ra/ occurs in between the base and the reduplicant, the stress shifts on the latter from the base. Phenomena of reduplication with a specific focus on the use of /rə/ are discussed in the current study using the constraints like ${ }^{*}$ CLASH, and STRESS-TO-RED, etc. This particular phenomenon is predominantly present in the case of verbs in Hadoti, which is a unique feature of this variety of Hindi.
\end{abstract}

\section{Keywords}

reduplication, discourse marker, prosody, Optimality Theory, Hadoti

\section{EL INICIO DE LA REDUPLICACIÓN A TRAVÉS DE MARCADORES DISCURSIVOS: EL CASO DEL HADOTI} Resumen

La reduplicación es un proceso morfológico común en muchas lenguas, particularmente en el sur de Asia. Este estudio se centra en el fenómeno de la reduplicación en Hadoti, en el cual se produce con la

* Amity Centre for Linguistic Studies, Amity University Gurgaon, Haryana, India.

* Department of Humanities \& Social Sciences, Indian Institute of Technology Ropar, Rupnagar 140001, Punjab, India. 
ayuda de un marcador discursivo /rə/, que funciona como un agente de énfasis en el proceso. Este marcador se encuentra entre la base y el reduplicante para expresar énfasis en la tarea, la acción o el verbo

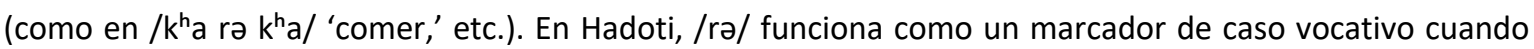
aparece al final de la oración como en /ram gjo rə/ "Ram fue". Sin embargo, cuando /rə/ ocurre entre la base y el reduplicante, el acento se desplaza hasta el último desde la base. Los fenómenos de reduplicación con un enfoque específico en el uso de /ra/ se analizan en el este estudio usando restricciones como *CLASH y STRESS-TO-RED, etc. Este fenómeno particular está predominantemente presente en el caso de los verbos en Hadoti, que es una característica única de esta variedad de hindi.

\section{Palabras clave}

reduplicación, marcador discursivo, prosodia, Teoría de la Optimidad, Hadoti

\section{Introduction}

In this study an attempt is made to explain a notion of verbal reduplication present in Hadoti focusing on two phonological features, i.e., syllable and prosody using Optimality Theory (OT), a grammatical framework proposed by Prince \& Smolensky (1993), McCarthy \& Prince (1993 a, b).

Hadoti is a regional variety of Hindi (Rajasthani) spoken by communities present near Kota region of the Indian state of Rajasthan. It is grouped under the Indo-Aryan family (Grierson 1908). Similar to other Indo-Aryan languages like Hindi, Gujarati, Bengali, etc., Hadoti displays productivity in its reduplication process. Several types of the process have been recorded from the field trip (November and December 2015) in Kota Rajasthan, i.e., complete, partial, echo-words, onomatopoeic and reduplication with the use of discourse markers.

Several examples of the process have been recorded during the field trip conducted in Kota Rajasthan, i.e., complete, partial, echo-words, name doubling, onomatopoeic and reduplication with the use of discourse markers. The specific type of reduplication phenomenon studied in this article is the case of reduplication which ensues with the help of a discourse marker hereafter, (DM) /rə/, functioning as an emphasizing agent in the process. Hadoti verbal reduplication process with discourse 
marker/particle forms only in present simple verbs or root verbs. The reduplication

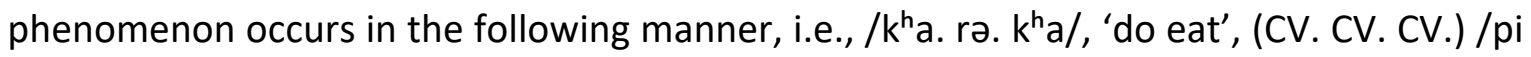
rə pi/ 'do drink' (CV. CV. CV.) and /kər. rə. kər/ 'must do' (CVC. CV. CVC.) This marker comes between the base and the reduplicant for expressing emphasis in work or action and quality of verb. In Hadoti, /rə/ functions as a vocative case marker when it comes at the end of the sentence. For instance, /ram gjo rə/ 'Ram went'. It is because of full reduplication process where nouns provide the morphological function whereas in verbal phenomena reduplicant forces the action. i.e., $/ k^{h} a$. rə. $k^{h} a /$, 'do eat'. It emphasizes the work. In Hadoti this kind of formation contains a semantics of its own. In other words, it can be said that such constructions do not need any other syntactic elements. For instance, */ram roti $\mathrm{k}^{\text {h}}$ a rə $\mathrm{k}^{\mathrm{h}} \mathrm{a} /$, 'Ram do eat bread'. This colloquial construction seems ungrammatical, while $/ k^{h} a$ rə $k^{h} a /$ 'do eat' has the meaning, but with a strong sense imperativeness. The most important point is that such formation cannot be made in the case of the third person in which case there is no participation or listening to the speakers.

Continuing on the point in this study, we try to explain one of the above types of reduplication processes initiated with discourse marker with complete verbal reduplication that is with a simple or root verb. However, as we have already discussed, when /rə/ occurs between the base and the reduplicant, the stress shifts on the reduplicant syllable from the base. The presented Hadoti reduplication phenomena have mostly monosyllabic words and, in some cases, disyllabic lexical items (verb). As noticed in the above examples, it can be stated that this particular phenomenon is predominantly present in the case of verbs in Hadoti, which is a unique feature of this variety of Hindi.

"Stress, tone, and intonation are described as part of the prosody of a language. Prosodic features of speech are those that are not predictable from the intrinsic properties of the consonants and vowels. Prosody is important to both phoneticians and phonologists. Phoneticians look for measurable properties of prosodic features, while phonologists traditionally try to explain prosody in an abstract framework" Dyrud (2001: 1). 
Stress is not prominent in Hadoti (like Hindi) as compared to the English language. Many linguists focused on the prosody of Hindi, but no one has taken Hadoti into account. "Some major studies have been conducted on Hindi and its phonological properties" (Dixit 1963: 124-5; cf. Dyrud 2001).

Over the years, many types of research on Hindi-Urdu word stress often agreed on the location of stress in a word, although they may disagree about other issues, such as the way stress is manifested phonetically in Hindi-Urdu. Fairbanks (1981; cf. Dyrud 2001) studied the use of stress patterns in Hindi-Urdu verse: "The literature strongly points to the view that speakers have intuitions with respect to the location of stress in Hindi-Urdu words. Generally, the location of word stress in Hindi-Urdu is predictable on the basis of syllable weight". Probably the simplest account of stress placement in Hindi-Urdu comes from Hussain (1997) wherein he states:

Based on the number of segments in the rhyme, Hindi-Urdu syllables can be classified as monomoraic or 'light' (V), bimoraic or 'heavy' (VV or VC), or trimoraic or 'super heavy' (VVC or VCC).

Given this definition, Hussain (1997) explains that the last heavy syllable is stressed, and if all syllables are light, the penultimate syllable is stressed. This account assumes a notion of extrametricality, which says the final mora of the word is invisible to the stress rule. Mohanan (1979, as cited by Pandey 1989: 41; cf. Dyrud 2001) first used extrametricality for describing stress in Hindi, and this notion has since been used in several other descriptions.

In a word, only one syllable, and in a phrase, only one word gets prominent stress; all other syllables and words are evenly stressed. Stress on these levels is non-lexical and predictable. Arun (1961: 21; cf. Dyrud 2001) claims that stress in Hindi "sometimes phonemic". By "sometimes" it is meant that in certain environments, a word may be stressed differently, leading to a few examples of words that contrast in stress only. He provides some examples /'galaa/ 'throat' and /ga'laa/ 'melt something'. He displayed the stress to build the different word identity and different meaning. Mehrotra (1965: 96; cf. Dyrud 2001) begins his work by saying: "Stress plays a vital part in Hindi, although 
not as vital as in English, or Russian, or Greek". There is not a single syllable that does not bear some degree of stress, but the weak stress has been considered to be "no stress phoneme", and the heavy stress has been regarded as "stress phoneme". His major claim is that stress in Hindi is used mainly for "emphasis" and for "contrast". It is found at the word level. He also gives some necessary criteria to judge the stress.

According to Mehrotra (1965), basic criteria to judge the stress

a) Influences of stress on the sounds and sound-attributes of the language

b) Stress makes a vowel tense and a consonant fortis

c) Stress causes some sounds to be longer than when they are in some unstressed syllables

d) Stress may double a consonant, e.g. /kat/ may be pronounced /katt/

e) Stress may introduce aspiration in an initial stop

f) Contrarily, an unstressed syllable may show the loss of aspiration somewhere in it

g) High and low vowels head towards the mid-central vowel if they are unstressed

h) Some rise in pitch of the sounds may also be an effect of the stress

i) Stress may also fall with an increase in pitch, Mehrotra (1965: 104-105; cf. Dyrud 2001)

On the basis of above-given parameters, it can be said that in Hadoti verbal reduplication process, the reduplicant has rising or increased pitch and sometimes sounds are more prolonged than when they are in an unstressed syllable (base). This can be considered as a reason for stress in the word. Therefore, the present paper will study the occurrence in the presented data of Hadoti verbal reduplication concerning stress or rise in pitch shifts to the reduplicant form of the base word. 


\section{Theoretical Framework}

Optimality Theory was proposed by Alan Prince \& Paul Smolensky in 1993. It was developed as a new theory of human language. In Optimality Theory structure phonological constraints are ranked and violable as discussed by Prince \& Smolensky (1993). These constraints are violated minimally by optimal surface forms (possible set of candidates), and a candidate which has least expensive violation (which violates lowest ranked constraints) wins or becomes the optimal candidate. The seriousness of the violation depends on the hierarchy of ranked constraints. Candidates' violation of higher ranked constraints is most serious. In OT, the constraints are broadly divided into two categories, namely, the markedness and the faithfulness constraints. Markedness constraints enforce well-formedness of output candidate prohibiting a structure that is difficult to produce or comprehend such as consonant clusters (Prince \& Smolensky 1993). On the other hand, faithfulness constraints impose a similarity between input and output. For instance, all morphosyntactic features in the input are to be overtly realized in the. OT has already been used to analyze different aspects of phonology in few Indian languages (see output Kar 2010; Dutta 2018, among others) As this theory is considered to be an apt tool for explaining typological features in various languages, the present study attempts to further establish its efficacy in Hadoti.

\section{The basic concept of Reduplication}

The discussed verbal reduplication process in the present article is the part of the complete reduplication process in Hadoti.

"Reduplication is an inherently synchronic process. The variability of the reduplicant can only be explained through the active creation of forms by speakers at the moment of production" (Zukoff 2012: 13).

Hadoti verbal reduplication process has three types. Reduplications like /sərək sərək/ 'shift' are examples of the type with simple of the base form. This kind of verbal construction is mainly available in standard language namely Hindi, if similar construction 
is used, especially in Hadoti, it would not be complicated to say that it is a borrowing from the standard Hindi into Hadoti. However, such construction in Hadoti is less acceptable rather than /sərək rə sərək/ 'do shift'. Second type of verbal reduplication process is a continuous form which displays the continuity of the action, For instance, /sərəkto sərəkto/ 'shifting', and the third one is the perfect form which manifests when there is completion of work; e.g., /kərjo kərajo/ 'done'. Thus, all forms show the same linguistic functions through reduplication as mentioned above. In the second type of reduplication process discussed here, the suffixes /ta/ and /to/ play the crucial role to define the continuity of the action with emphasis and describe the morphological feature in the form of singularity and plurality. In this /to/ is used for singular and /ta/ is for plural. Interestingly, this morphological feature of singularity and plurality present in Hadoti is just opposite to Hindi. In Hindi /to/ is used for creating singularity and /ta/ for plurality. The last type of construction present in Hadoti has one syllable /jo/ affix added as a suffix to the root verb and epenthesis of the long vowel /a/ before the suffix, therefore; in reduplicant, a vowel segment insertion also happens with added syllable. This vowel segment /a/ insertion is because of sonority sequencing principle as it says that there should not be sonority rise across the syllable boundary to make such construction less marked in the language.

Morphological features do not affect the stress pattern in Hadoti verbal reduplication. In verbal construction suffix addition to the root verb which does not carry the stress (suffix addition to the root verb does not alter the stress placement), the same phenomena are evident in Hindi (Hayes 1995, Pandey 1989, Kelkar 1968), Punjabi (Dhillon 2007) and Sindhi (Walker 1997). Hadoti is closely related to Hindi. The morphological process of suffixation, which does not alter the stress placement in a word, can be seen in Hadoti through the Praat Analysis in (3). In which /to/ is a suffix added to the root word $/ \mathrm{k}^{\mathrm{h}} \mathrm{a} /$, where root verb $/ \mathrm{k}^{\mathrm{h}} \mathrm{a} /$ is prominent syllable and /to/ is not a prominent syllable in a disyllabic word. The prominence is on the base because such constructions are borrowed from Hindi in which no particle added between the base and the reduplicant. While in Hadoti, particle between the verbal root base and reduplicant is the essence of the Hadoti reduplication process. Without particle root, verbal 
reduplication is almost none in Hadoti. It can be seen in rare cases only. Therefore, it can be said that in Hadoti root verbal reduplication process discourse particle/marker play a crucial role in word formation process and emphasis on the action/work, this kind of reduplication formation is possible only with simple root verbs, which have both mono and disyllabic structure.

\section{Types of reduplication in Hadoti}

Reduplication phenomenon is widespread in most languages of the world. Some languages have only complete, and some have both complete and partial reduplication, and some have many more types of reduplication. Hadoti has following types of reduplication process.

(1) Reduplication and its type

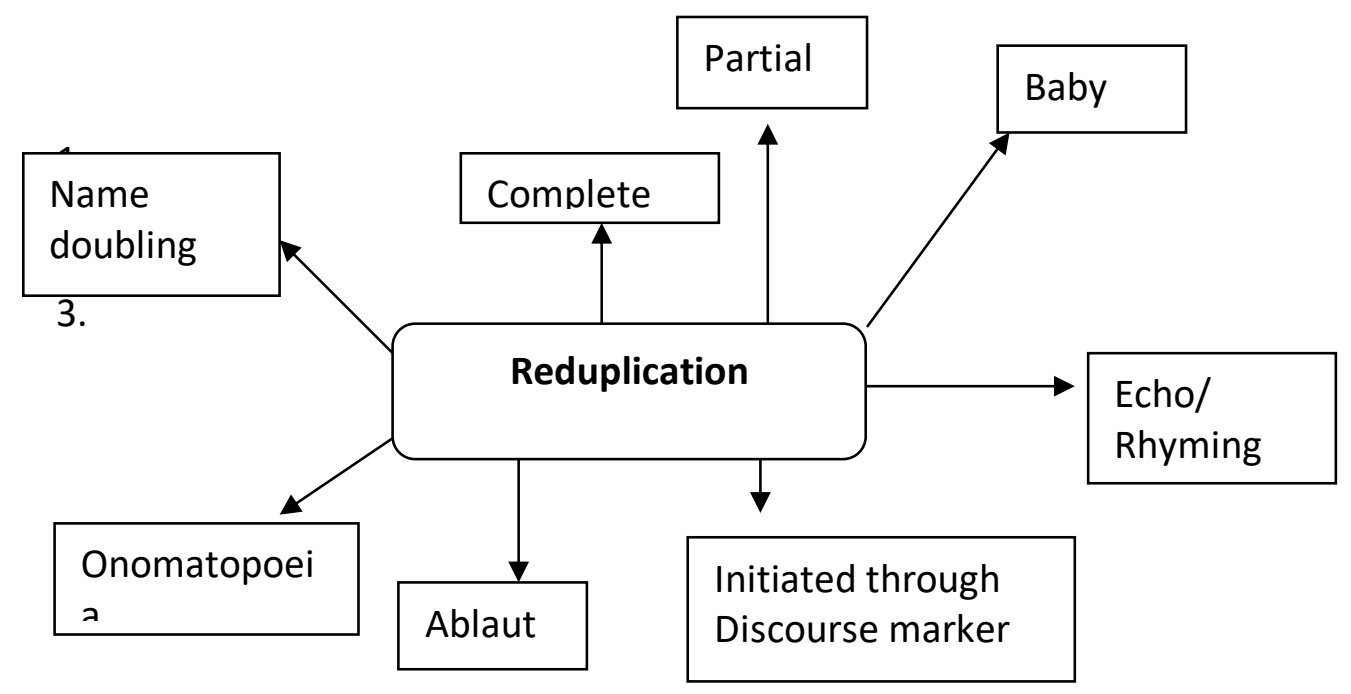

Before moving further, we must understand the types of the reduplication process with the help of a brief definition and examples of (1).

A. Complete/Total reduplication: This kind of reduplication applies the doubling or repetition of a root, stem or word, with no phonological modifications like, $/ k^{\text {h }}$ ato $k^{\text {h }}$ ato/ 
'while eating', /pito pito/ 'while drinking'. Reduplication initiated through DM also comes under complete reduplication process.

B. Partial Reduplication: In this reduplication process Repetition of a root, stem or word, with minimal phonological modifications, deletion and an addition like /roti oti/ 'bread and such'. Echo/Rhyming words are also part of the partial reduplication.

C. Name doubling: This is also one of the complete reduplication processes in which only proper names will be pronounced with repetition, like, / $\mathrm{ram}$ ram/ 'name of load rama', / Jjam Jjam/ 'name of Lord Krishna' and /rad' $\mathrm{rad}$ he/ 'name of the goddess'.

D. Onomatopoeic reduplication: This kind of reduplication process defines imitating animals and sounds in nature as, $/ p^{\text {h}} \partial d p^{h} \partial d /$ 'sound of flounder'.

In the current study, we mainly discuss the one of complete reduplications process that is initiated through discourse marker/ro/. This construction occurs only with root verbal reduplication. No other discourse marker can take part to form reduplication in Hadoti; therefore, reduplication process with DM /ro/ form the special and completely different kind of reduplication process.

\section{Discourse marker in Hadoti Reduplication}

The discourse markers in pragmatics work as a functional tool, which comes under a group of expressions. These are often known as discourse particles and discourse operators. The function typically includes the feature of emphasis in a particular kind of reduplication process in Hadoti. The feature is /ro/ between the complete verbal reduplication. This kind of reduplication process is not common in the Indian languages, but this kind of reduplication is explained as reduplication in Alamblak language of Papua Guinea. Bruce (1984: 164-165) states that "Stems formed by reduplication are the most cohesive of the serial verb constructions. A repeated verb root may be either juxtaposed or joined by a ligature (LIG), i.e., hingna -marna -ba -marna -me -r 'He worked very well'" In the above example, /ba/ works as a ligature, and it separates the verbal reduplication. Hence this phenomenon exists in the Papua Guinea language. In Hadoti 
/rə/ works as a particle between the verbal reduplication. /rə/ is exclamative particle in Hadoti (Dwivedi 2012: 7).

The use of these particles with different word classes covers a wide range of meanings and further shades of meanings when used in their combination with various word classes. The particles are very commonly used in Indian languages. The particles cover a wide range of meanings and further shades of meanings when used in combination with various parts of speech (Mahanta 2015).

Particles play a very critical role in the language. Hadoti also has the particles as a linguistic feature.

Hadoti particles never occur sentence initially. Some of them can occur only at the final position, while others can occur just at the sentence-medial position. However, a subclass can appear both in final and in medial position. The following table shows the location of particles in the Hadoti.

(2) Discourse markers in Hadoti

\begin{tabular}{|c|c|c|}
\hline Discourse markers & medial & final \\
\hline न nə & - & + \\
\hline r ra & + & + \\
\hline क ka & - & + \\
\hline तो to & + & + \\
\hline ही $h i$ & + & + \\
\hline ची/छी $\quad t i / t^{h} i$ & + & - \\
\hline भी & + & \\
\hline सारो & + & + \\
\hline बस & + & + \\
\hline जे $d z e$ & + & + \\
\hline
\end{tabular}

The particles are generally attached to a particular word in a sentence for denoting emphasis and contrast, among others. Mahanta (2015) discusses the case of particles with different word classes wherein these cover a wide range of meaning and further shades of meanings when used in their combination with various word classes. Here we 
ask the following questions: How do particles play a role in reduplication process? How can particle phonological analysis be done? What are the OT constraints work to describe reduplication with particles?

The main particles used in Hindi are 'bhii', 'hii', 'to', 'tak'. 'bhar' and 'maatra' (Mahanta 2015). Similarly, the main particles used in Hadoti are / $\mathrm{b}^{\mathrm{h}} \mathrm{i} /, /$ to/, /hi/, /saro/, /rə/ and /bəs/. In Hadoti verb reduplication process the /rə/ particle is appropriate for serving to emphasize on the action. In verbal reduplication process /rə/ is used instead of /hi/. Because the verbal reduplication constructions form the meaning like $/ \mathrm{t}^{\mathrm{h}}$ ai jo kərno hi th $t^{\text {h}} /$ 'you have to do it.' While without DM the sentence would be / $t^{h}$ ai jo karno $t^{h} \partial /$ 'you do it.' The difference in the meaning is with DM as someone is forcing to do the particular work whether the doer is interested or not and in without DM sentence a person is telling the work to someone that you do it. Such a way in Hadoti verbal reduplication /rə/ is acting like /hi/. Because of DM in reduplication process, the prominence of the syllable is shifting from the base to reduplicant. Hence it is proved that a DM is playing a role in stress shifting as well as the changes in the meaning in a specific context.

\section{The Basic Properties of Stress in Hadoti}

Hadoti also displays three-way distinction in syllable weight with monomoraic light syllables, bimoraic heavy syllables, and trimoraic superheavy syllables. In Hadoti monosyllabic word has prominence while disyllabic word second syllable has prominence. It is because of the heaviness of the syllable weight, lengthening, and duration of the particular syllable. Monosyllabic words may have CV or CVC. If CV syllable has a long vowel, then it carries two morae, while in reduplicant CV has short vowel then it has a longer duration than a neighbouring syllable. In a disyllabic word, the heavy syllable gets prominence based on vowel or mora. Therefore, it can be said that in disyllabic words morphological elements cannot be considered as prominence syllable in the language. It can be seen in given below figure. So far monosyllabic and disyllabic 
words of Hadoti are shown. Later in this research trisyllabic word will be discussed with /rə/ insertion between the base and reduplicant as one more syllable. As Mehrotra (1965) gives some parameters for Hindi and one of them is taken here to identify the stress or prominence in the Hadoti that is "some rise in pitch of the sounds may also be an effect of the stress".

In Hadoti, complete verbal reduplication without/ro/ insertion, stress or prominent syllable is always in the base form.

(3) Spectrogram showing high pitch of base form without DM

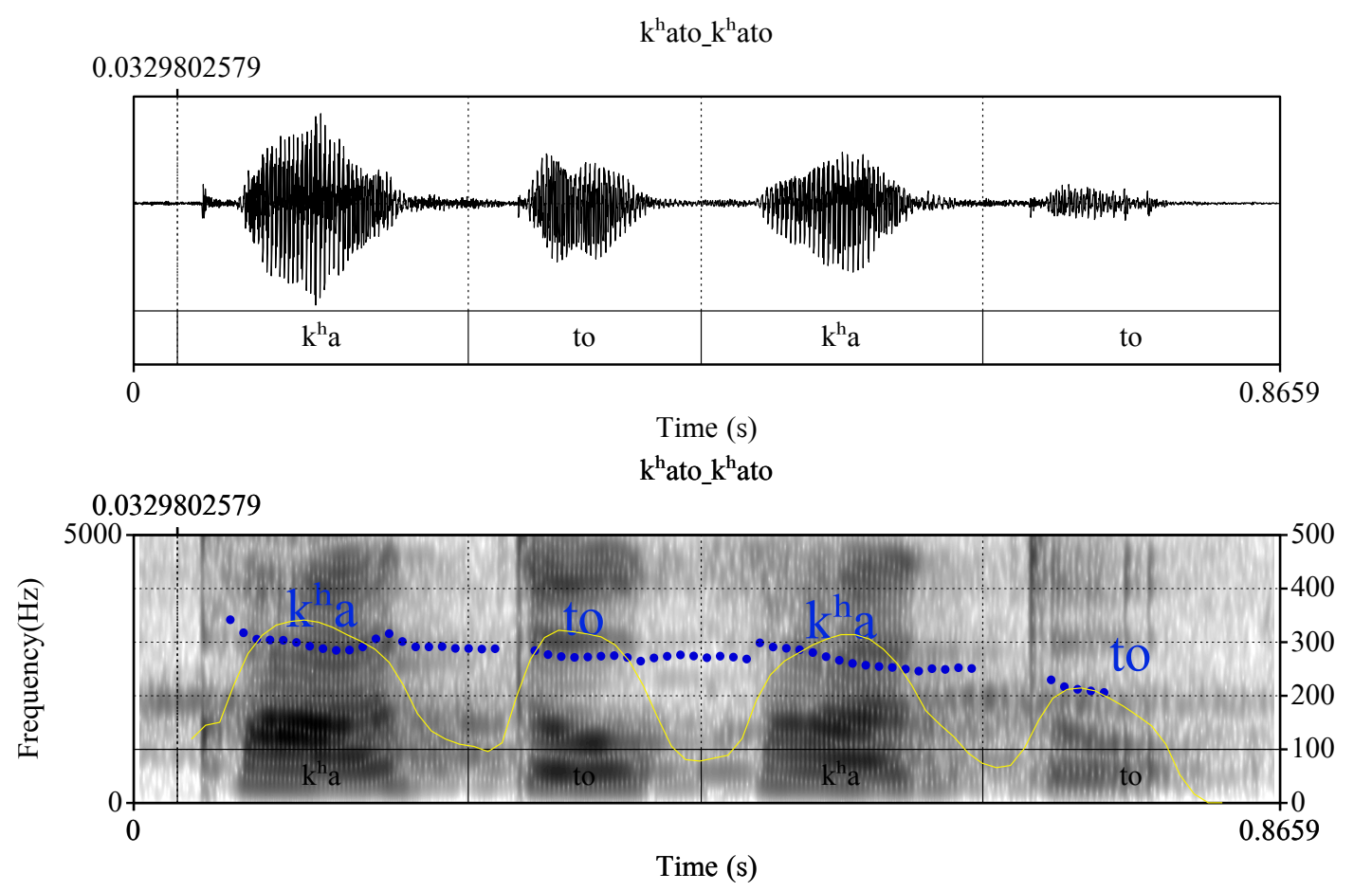

In the above picture, we see that the prominent syllable shows the high pitch through contour the first syllable of the base has pitch height between 3000 and 4000 $\mathrm{Hz}$. This prominence shows the stressed syllable in a given the word. Hence it can be said that in full verbal reduplication stress is on base form while verbal reduplication initiated through DM stress shifts on the reduplicant, which can be seen in below figures $(4,5$ and 6) where the prominent syllable is at the right edge syllable of the word. Sometimes it may vary according to syllable weight, but the maximum time the reduplicant gets stress in mono and disyllabic words. The discussed analysis claims that Hadoti does have phonetic stress based on the pitch study results. 


\section{Reduplication and Prosody feature}

Hindi syllable structure is agreed that Hindi syllables exhibit contrastive weight. Weight is related both to the vowel length and occurrence of postvocalic consonants Pierrehumbert \& Nair (1996). "Prosodic features of speech are those that are not predictable from the intrinsic properties of the consonants and vowels. Stress is the relative prominence of syllables. Among the syllables of a word, one syllable usually stands out as more prominent than the other syllables" (Dyrud 2001). "Prosody phenomena are explored in the domain of higher phonological constituents such as word, phonological phrase and intonational phrase. The study of prosody at the word level is called word prosody, and above word level is called sentence prosody" (Roy 2017).

Mostly the location of lexical stress in any language is predictable through the syllable weight. Hayes (1991) shows three-ways weight distinction is reflected in the stress patterns. These are the following.
a. $\mathrm{C} \mu \quad$ L(Light)
kə.la 'art'
b. $\mathrm{C} \mu \mu \mathrm{H}$ (Heavy)
ka.la 'black'
c. $C \mu \mu \mu \mathrm{S}($ Superheavy) kan.ta 'thorn' ('restricted occurrence'; Hayes 1991)

Hence, a syllable is heard as more salient than others. Stress in Indian languages is represented through vowels length or duration and moraic weight. In this article stress pattern of Hadoti reduplication process is being shown. The present data have been analyzed in Praat and found that in reduplication process with discourse marker (DM). In this process, DM works as a ligature. According to the above definition of stress, the most prominent syllable bears the stress. Presented data analysis claims that the last syllable (reduplicant) of the process bears the stress. i.e., /mər rə mər/, 'do die' /tfal rə tfal/ 'do walk' etc. the last syllable is stressed syllable. The time duration and lengthening of last syllable utterance is more than previous syllables. It can be seen in the following figures. 
(4) Spectrogram showing high pitch of reduplicant with DM
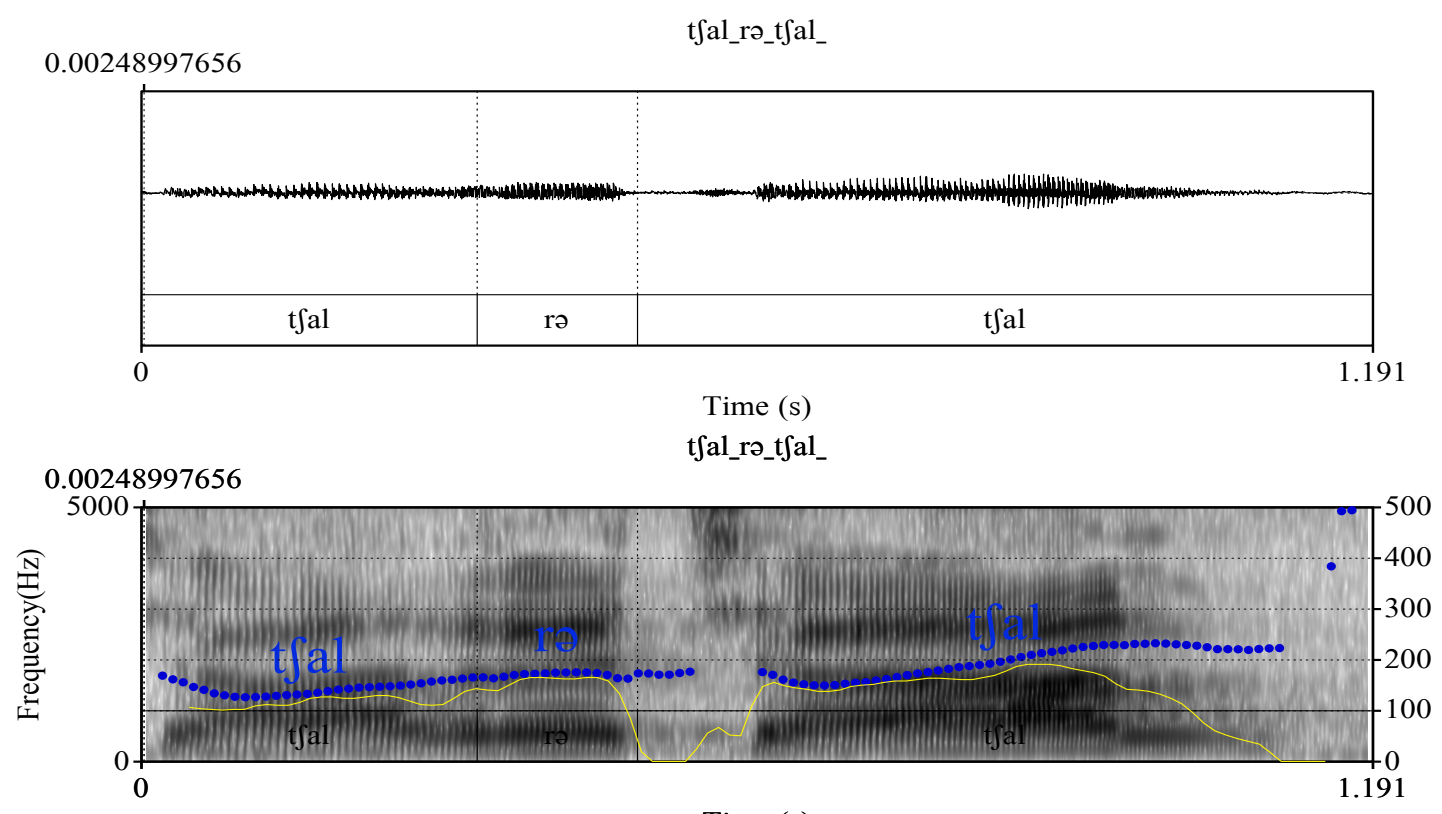

Time (s)

(5) Spectrogram showing high pitch of reduplicant with DM

bal_re_bal

0.534224716

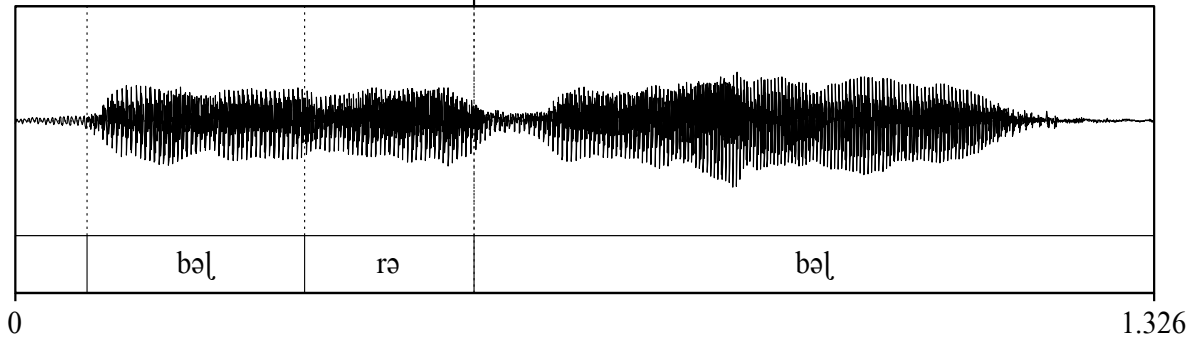

Time (s)

bal_re_bal

0.534224716

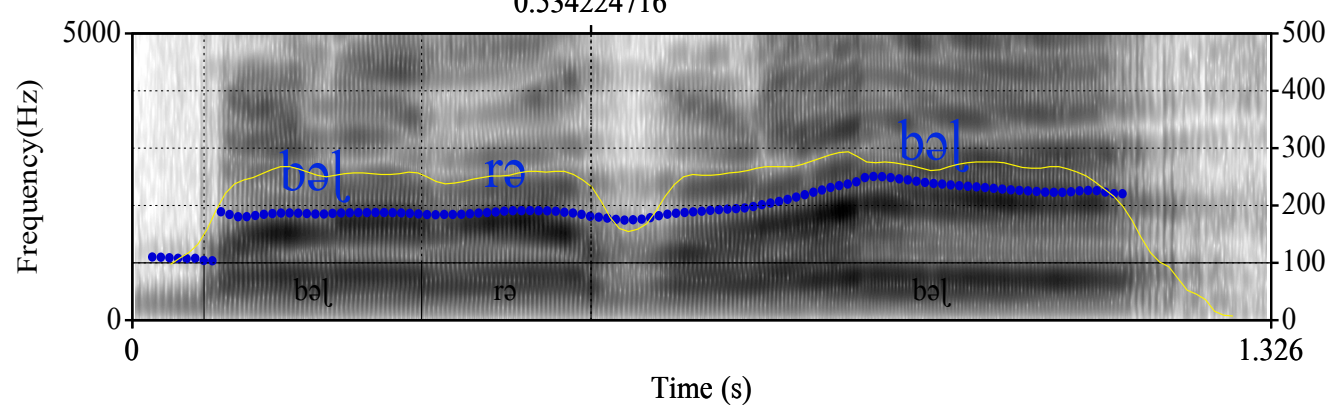


(6) Spectrogram showing high pitch of reduplicant with DM

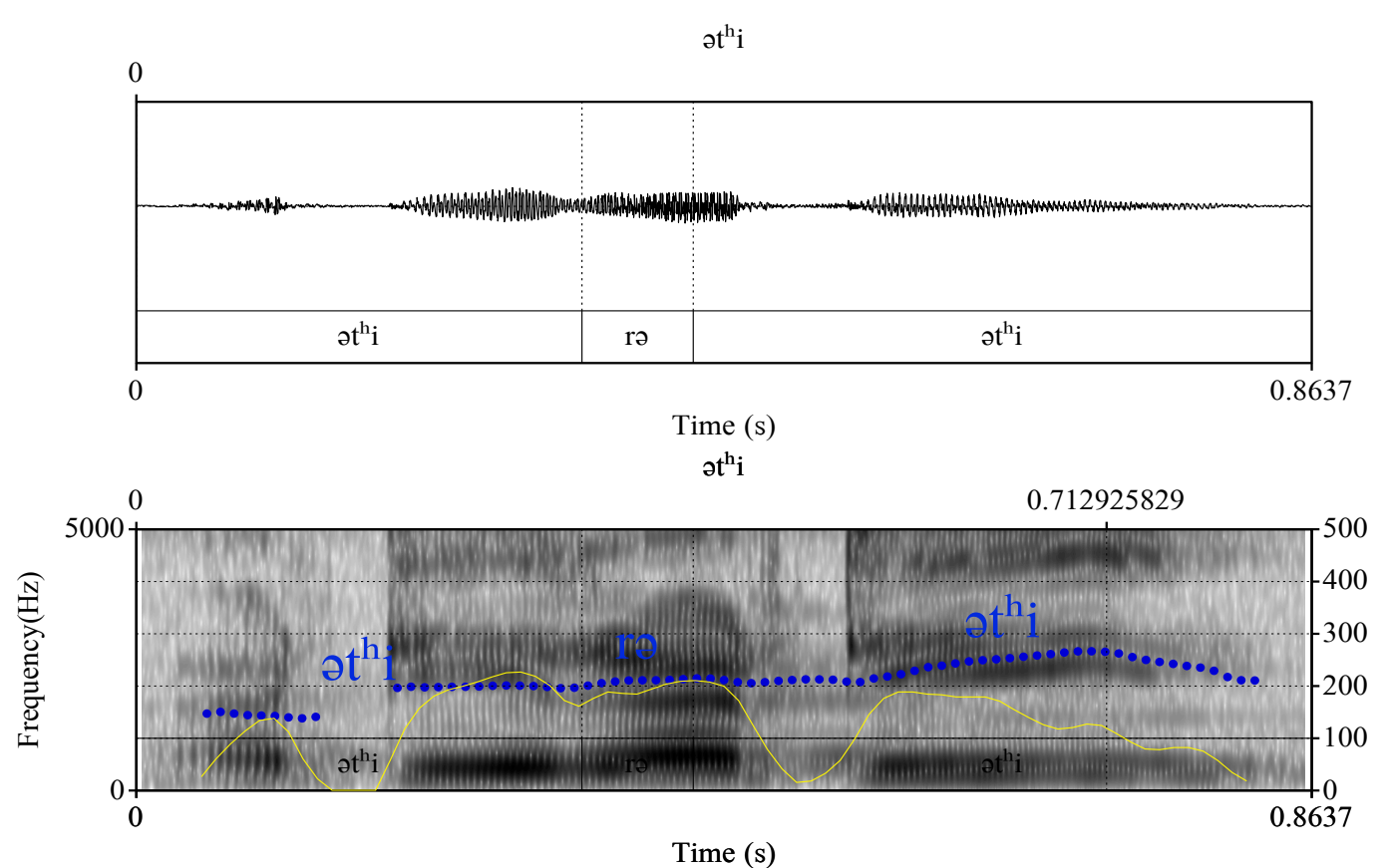

\section{Syllable shape of the Reduplication}

Explaining the data as presented, it shows the shape of the Hadoti complete reduplication process, which initiated through discourse marker, has $\mathrm{V}, \mathrm{VC}, \mathrm{CV}, \mathrm{CVC}$, and CVCC, while the discourse marker has CV.

\subsection{List of the Hadoti onomatopoetic words}

The primary source of data is the speech of 25 native speakers from the different rural area of four districts of Hadoti division, namely, Kota, Baran, Jhalawar, and Bundi. The data selected on the basis of phonological and morphological considerations. 


\begin{tabular}{|c|c|c|c|}
\hline \multicolumn{2}{|c|}{ (a) Root Verb } & \multicolumn{2}{|c|}{ (b)Verbs with Continuity } \\
\hline Base & Reduplication & Base & Reduplication \\
\hline /kər/ 'to do' & /kər ra kər/ 'do do' & /knato/ 'eating' & $\begin{array}{l}\text { / } \mathrm{k}^{\mathrm{h}} \text { ato } \mathrm{k}^{\mathrm{h}} \text { ato/ 'while } \\
\text { eating' }\end{array}$ \\
\hline /mər/ 'to die' & /mər ra mər/ 'do die' & /pito/ 'drinking' & $\begin{array}{l}\text { /pito pito/ 'while } \\
\text { drinking' }\end{array}$ \\
\hline$/ k^{h} a /$ 'to eat' & $/ k^{h} a$ rə $k^{h} a /$ 'do eat' & /mərto/ 'dying' & $\begin{array}{l}\text { /mərto mərto/ 'while } \\
\text { dying' }\end{array}$ \\
\hline /mãnd/ 'to draw' & /mãnd rə mãnd/ 'do draw' & /soto/ 'sleeping' & $\begin{array}{l}\text { /soto soto/ 'while } \\
\text { sleeping' }\end{array}$ \\
\hline$/$ bət ${ }^{\mathrm{h}} /$ 'to sit' & $/$ bət $^{\mathrm{h}}$ rə bət $\mathrm{t}^{\mathrm{h}} /$ 'do sit' & /kərto/ 'doing' & $\begin{array}{l}\text { /kərto kərto/ 'while } \\
\text { doing' }\end{array}$ \\
\hline $\begin{array}{l}\text { /prd/ 'to } \\
\mathrm{read} / \mathrm{study} \text { ' }\end{array}$ & $\begin{array}{l}\text { /pəd rə pəd/ 'do } \\
\text { read/study' }\end{array}$ & & \\
\hline /sərək/ 'to shift' & /sərək rə sərək/ 'do shift' & & \\
\hline /tfal/ 'to walk' & /tgal rə tal/ 'do walk' & & \\
\hline /so/ 'to sleep' & /so ra so/ 'do sleep' & & \\
\hline /pi/ 'to drink' & /pi rə pi/ 'do drink' & & \\
\hline
\end{tabular}

Table 1. Root Verbal Reduplication

\section{Analysis}

Since the stress parameters and Praat analysis show that Hadoti also has the stressed or prominence syllable in its prosodic words. As we mentioned in the introduction that in Hadoti there are three types of verbal reduplication process, i.e., one complete segment copied, which shows the continuity of the action (/kərto kərto/ 'doing'), second root verbal reduplication with discourse marker /rə/ (/mãnd rə mãnd/ 'do write/ draw), and third and last with /a/ epenthesis in reduplicant, which shows or describe the perfection of work/action. In this study, we are trying to put focus mainly 
root verbal reduplication along with two more types of reduplication process discussed before.

Input segments must have output correspondents (No deletion).

This is a faithfulness constraint which requires the complete identity between input and output.

(8) BR-IDENT(stress) Zukoff (2015)

Assign one violation mark * for each syllable in the reduplicant in which the presence or absence of stress differs from the corresponding syllable of the base.

This is one of the correspondences constraints that require the identity between base and reduplicant, which is a lower ranked constraint in the given ranking for Hadoti verbal reduplication.

(9) * CLASH: Stanton \& Zukoff (2015)

Assign one * for every sequence of two adjacent stressed syllables.

*CLASH is a prosodic markedness constraint that does not allow two consecutive stressed syllables.

(10) STRESS-TO-RED: Zukoff (2015)

All reduplicants must have at least one stressed more.

The constraint is one of the prosodic markedness constraints that requires at least one stressed mora in the reduplicant. 
(11) OneStress:

Gordon (2004)

A word has one and only one stressed syllable.

This constraint is one of the prosodic markedness constraints that requires at least one stressed syllable in a prosodic word.

(12) /rə/on:

/ra/ must be between root verbal reduplication.

The constraint is one of the markedness constraints that requires only /rə/ between root verbal base and reduplicant.

(13) Monosyllabic Reduplication with DM

\begin{tabular}{|c|c|c|c|c|c|c|}
\hline $\begin{array}{l}\text { INPUT: /tfal/ } \\
\text { [RED] }\end{array}$ & MAX-IO & /rə/on & ${ }^{*} \mathrm{CLASH}$ & $\begin{array}{l}\text { One } \\
\text { Stress }\end{array}$ & $\begin{array}{l}\text { STRESS- } \\
\text { TO-RED }\end{array}$ & $\begin{array}{c}\text { BR-IDENT } \\
\text { (stress) }\end{array}$ \\
\hline a. /tfal rə 'tfal/ & & & & & & $*$ \\
\hline b. /'tyal 'tfal/ & & $* !$ & $*$ & $*$ & $*$ & \\
\hline c. /al rə tal/ & $* !$ & & & & $*$ & \\
\hline d. /'tgal'rə'tfal/ & & & $* !$ & $*$ * & & \\
\hline e. /'tyal rə 'al/ & $* !$ & & & $*$ & & \\
\hline f. /'tfal rə 'tfal/ & & & & $* !$ & & \\
\hline
\end{tabular}

(14) Disyllabic Reduplication with DM

\begin{tabular}{|c|c|c|c|c|c|c|}
\hline INPUT-/sə.rək/ [RED] & $\begin{array}{l}\text { MAX- } \\
10\end{array}$ & $\begin{array}{l}\text { /rə/ } \\
\text { on }\end{array}$ & ${ }^{*} \mathrm{CLASH}$ & $\begin{array}{l}\text { One } \\
\text { Stress }\end{array}$ & $\begin{array}{l}\text { STRESS- } \\
\text { TO-RED }\end{array}$ & $\begin{array}{c}\text { BR- } \\
\text { IDENT(stress) }\end{array}$ \\
\hline a. /sə.rək. rə. 'sək./ & $* !$ & & & & $*$ & \\
\hline b. /ə.rək. rə. sə.rək/ & $* !$ & & & & $*$ & $*$ \\
\hline c. & & & & & & $*$ \\
\hline d. /sə. 'rək. 'rə. sə. 'rək/ & & & $* !$ & $*$ & & \\
\hline e. /sə. 'rək. 'sə.rək/ & & $* !$ & $*$ & $*$ & $* !$ & \\
\hline f. /'sə. rək. 'rə. sə. 'rək/ & & & & $* !$ & & \\
\hline
\end{tabular}


The above tableaux exhibit that in (13) candidate (a), and (14) candidate (c) are the optimal candidates because they passed all the higher ranked constraints and violated the lowest ranked constraints BR-IDENT(stress). The higher ranked constraint is MAX-IO which is violated by candidates (c \& e) in (13) and (a \& b) in (14). These candidates are making fatal violation and are removed from the competition. The second constraint is ${ }^{*}$ CLASH which requires the one * violation mark for every sequence of two adjacent stressed syllables. This condition is violated by candidates ( $b$ and $d$ ) in (13) and ( $d$ and e) in (14). In other words, no adjacent stressed syllable be present in between base and reduplicant. The second higher ranked constraint is /rə/on which provides the condition that /rə/ must be between root verbal reduplication. This /rə/ is a discourse marker that makes the verbal reduplication process in Hadoti unmarked. This constraint demands the infix the extra CV syllable between base and reduplicant so in both tableaux candidates (b) in (13) and (a) in (14) violate the condition of the constraint and get the fatal violation. The next constraint One Stress requires only one stress at the word level. This constraint is violated twice by (13) (d) and once by (13) (e) because the candidates have more than stressed syllable and this is not the feature of Hadoti language. In (14) candidate (d) has two stress marks in the word which is a marked construction in Hadoti language. The second last constraint in the above tableaux is STRESS-TO-RED that assign the violation mark for those candidates which do not have stress on reduplicant. Hence candidates ( $b$ and $c$ ) in (13) again get the violation marks, while in (14) candidates (a, b and e) also get the violation. Thus, through this ranking competition, candidate (a) (13) and (c) in (14) get the least violation and become the optimal candidate. As discussed above in section (7), Hussain (1997) states that the last heavy syllable is stressed, and if all syllables are light, the penultimate syllable is stressed, therefore, in tableau (14), the last syllable gets the stress because it is heavy syllable in the word. Hence, this ranking exhibits the emergence of unmarked. 
(15) Disyllabic Reduplication without DM

\begin{tabular}{|c|c|c|c|c|c|c|}
\hline $\begin{array}{l}\text { INPUT-/tyalto/ } \\
\text { [RED] }\end{array}$ & $\begin{array}{l}\text { MAX- } \\
\text { IO }\end{array}$ & $\begin{array}{l}\text { /ra/ } \\
\text { on }\end{array}$ & ${ }^{*} \mathrm{CLASH}$ & OneStress & $\begin{array}{l}\text { STRESS-TO- } \\
\text { RED }\end{array}$ & $\begin{array}{c}\text { BR-IDENT } \\
\text { (stress) }\end{array}$ \\
\hline $\begin{array}{l}\text { a. } \cos / \text { 'tfal.to } \\
\text { tyal.to/ }\end{array}$ & & & & & * & \\
\hline b. /'tal.'to tal.to/ & & & $* !$ & * & * & \\
\hline c. /al.to tal.to/ & $* !$ & & & & $*$ & $*$ \\
\hline d. /'tfal.to 'tfal.to/ & & & & $* !$ & * & \\
\hline e. /'tfal tfal.'to/ & $* !$ & & & $*$ & * & \\
\hline
\end{tabular}

Comparing the above tableaux (13 and 14) with (15) wherein the input is continuous verb form with the one extra morpheme /to/ added to the root verb / fal/. In this form, stress remains on the base form and does not shift from base to reduplicant. This instance is the opposite case /counter of the previously discussed analysis where stress shifted on the reduplicant from the base form. In (15) candidate (a) becomes the optimal candidate and has the least expensive violation in the constraint interaction process. Candidates ( $c$ and $d$ ) gets the punishment from highest ranked constraint MAXIO, while candidate (b) gets the punishment from the second highest ranked constraint *CLASH. Candidate (b) has two adjacent stressed syllables, and in Hadoti morphological components do not get the stress. Candidate (d) gets the punishment at prosodic markedness constraint, namely, OneStress, and all the candidates including candidate (a), which is optimal candidate violate the lower ranked constraint STRESS TO RED that requires the reduplicant must be stressed. In the above (15) case, faithfulness constraints dominate markedness constraints, and markedness constraints dominate the correspondent constraints (reduplicant identity), and the result of this ranking is the emergence of unmarked. 
(16) Disyllabic Reduplication without DM

\begin{tabular}{|l|c|c:c|c|c|c|}
\hline $\begin{array}{l}\text { INPUT: } \\
\text { /sə.rək.to/ [RED] }\end{array}$ & $\begin{array}{c}\text { MAX- } \\
\text { IO }\end{array}$ & /rə/ on & *CLASH & One & $\begin{array}{c}\text { STRESS- } \\
\text { TO-RED }\end{array}$ & $\begin{array}{c}\text { BR-IDENT } \\
\text { (stress) }\end{array}$ \\
\hline a. /sə.'rək.to. sə.'rək.to/ & & & & Stress & & \\
\hline b./'sə. 'rək. sə.rək.to/ & $* !$ & & $*$ & $*$ & & \\
\hline c. /sə.rək.to. sə.rək/ & $* !$ & & & & & $*$ \\
\hline d. /sə.'rək.'to. sə.rək.to/ & & & $* !$ & $*$ & & \\
\hline e. 1 /sə.'rək.to. sə.rək.to/ & & & & & $*$ & \\
\hline
\end{tabular}

With similar ranking, the present tableau (16) also displays the optimal candidate (e) in verbal reduplication representing the continuity of action in Hadoti. Candidate (a) gets the violation at third-ranked constraint One Stress because this constraint requires only one stressed syllable in the word. Candidate (b) is punished by the highest ranked constraints MAX-IO, ${ }^{*} \mathrm{CLASH}$, and One Stress. The candidate gets the violation at the highest ranked constraints in the present OT analysis, which is considered to be a fatal violation and gets itself out of the competition. The given ranking is able to deal with such kind of phenomena in Hadoti reduplication process. With the help of this ranking once again the result is the emergence of unmarked (TETU).

\section{Discussion}

The analysis above established that prosody feature like the stress of Hadoti Reduplication can be illustrated within Optimality Theory with the help of Markedness constraints, these constraints are ranked between faithfulness and correspondence (reduplicative identity) constraints in the hierarchy. In (13), (14), (15) and (16) we presented a ranking for verbal reduplication process in Hadoti. In this study, we discussed two forms of verbal reduplication process, i.e., reduplication initiated through discourse marker and reduplication with extra morpheme /to/ that forms the continuous form of the verb with the same ranking and presented ranking provides us with an 
optimal candidate in $(13,14,15$ and 16). Tableaux (13 and 14) are the analysis of reduplication with $\mathrm{DM} / \mathrm{r}$ / and (15 and 16) continuous verb form without DM.

It demonstrated the schema wherein ranking of the constraints explained that the Markedness constraints emerge between the Faithfulness constraints and Correspondence or Reduplicative Identity. The schema of the constraint hierarchy can then be said as following this hierarchy: Faithfulness constraints >> Markedness constraints >> Reduplicative Identity (correspondence). Prosodic markedness constraints, i.e., ${ }^{*}$ CLASH, One Stress, STRESS-TO-RED constraints are markedness constraints while MAX-IO is faithfulness constraint whereas BR-IDENT(stress) constraint is under the Reduplicative Identity (Correspondence) constraint. This ranking results in the emergence of unmarked (TETU). Hence, the final schema of the ranking is following

Faithfulness constraints > Markedness constraints >> Reduplicative Identity (correspondence).

\section{Conclusion}

To summarise, the present study has enumerated that Optimality Theory is an apt tool for describing the phenomenon of prosody in reference to reduplication process in Hadoti. As mentioned in the study prosody in phonology referred to the rise in the pitch contour or lengthening and duration of a syllable in compare to neighboring syllables in the given words. Moreover, in verbal reduplication process, the monosyllabic word the syllable of the base gets the stress while in disyllabic verbal base the last syllable (rightmost) will get the stress. In Hadoti stress marking is based on the syllable weight. In a disyllabic word, the send syllable has the syllable weight that is why it becomes the stressed syllable. However, in Hadoti verbal base and reduplicant do not occur without the discourse marker /rə/ it occur without it, it is the dominance of the Hindi. Without /rə/ verbal reduplication in Hadoti is not marked but not fully unmarked. In the present study, it is shown that when verbal reduplication happens without discourse marker, then the stress is always in the base form as shown in the above spectrogram (3) where the pitch is high compared to the other syllable in the word. Whenever the discourse 
marker /rə/ comes in between the verbal base and reduplicant, the stress shifts from base to reduplicant as shown in the spectrogram (4) onwards. Hence it can be generalized that in Hadoti verbal reduplication process the stressed syllable would be the rightmost syllable.

These prosodic properties in the Hadoti verbal reduplication process analyzed under the Optimality Theoretic framework, which is the constraint-based approach of phonological analysis. The data was presented in the tableaux and constraints are arranged that the hierarchy of the ranked constraints for the examples played a crucial role to justify or get the optimal candidate in the said language. In particular, section 14 showed how the Correspondence constraints MAX-BR (faithfulness) and Markedness constraints, i.e., /rə/on, One Stress, and Stress to Red played a vital role to get an optimal candidate concerning Prosody. That constraint punished all the candidates, which did not fulfill the requirement of the ranked constraint. The ranking hierarchy shows the emergence of unmarkedness. The schema of the ranking will be Faithfulness >> Markedness constraints > Faithfulness (correspondence). Concluding, constraints in Optimality Theory were able to describe the verbal reduplication and prosodic features in Hadoti.

\section{References}

ARUN, V. B. (1961) A Comparative Phonology of Hindi and Punjabi, Ludhiana India: Punjabi Sahitya Akademi.

BRUCE, L. P. (1984) The Alamblak Language of Papua New Guinea (East Sepik), Pacific Linguistics, Canberra: The Australian National University.

DhILLoN, R. (2007) "Stress in Punjabi", Berkeley Linguistics Society and Linguistics Society of America, 33(1), 84-95.

DIXIT, R. P. (1963) The segmental phonemes of contemporary Hindi, Master's Thesis, Austin: University of Texas.

DUTTA, H. (2018) "Gemination and segmental patterns with reference to Sanskrit and Assamese: An OT account", Lingua, 203, 102-118. 
DWIVEDI, A. V. (2012) A Grammar of Harauti, Languages of the world, München: Lincom Europa, 485.

DYRUD, L. O. (2001) Hindi-Urdu: Stress accent or non-stress accent?, Doctoral dissertation, University of North Dakota.

FAIRBANKS, C. E. (1981) The development of Hindi oral narrative meter, Unpublished Dissertation. Madison: University of Wisconsin.

GORDON, M. (2002) "A Factorial Typology of Quantity-Insensitive Stress", Natural Language \& Linguistic Theory, 20(3):491-552.

GrIERSON, G. A. (1968) (reprint) Linguistic Survey of India, vol. 1 Part I \& vol. IX Part II. Delhi: Motilal BanarasiDass

HAYES, B. (1995) Metrical Stress Theory: Principles and Case Studies, Chicago: University of Chicago Press.

HusSAIN, S. (1997) Phonetic Correlates of Lexical Stress in Urdu, North-western University. (Doctoral Dissertation).

KAGER, R. (1999) Optimality Theory, Cambridge: Cambridge University Press.

KAR, S. (2010) The syllable structure of Bangla: An Optimality-Theoretic Approach, Newcastle: Cambridge Scholar Publishing.

KelKaR, A. R. (1968) Studies in Hindi Urdu, Pune: Decan College.

MAHANTA, S. (2015) "The use of particles in Hindi and Assamese", International Journal of Research in Social Sciences and Humanities, 5, III, Jul-Sep, 113-124.

McCarthy, J. J. \& PRINCE, A. (1993a) "Generalized alignment," in G. Booij \& J. Van Marle (ed.), Yearbook of morphology 1993, Dordrecht: Kluwer.

MCCARTHY, J. J. \& PRINCE, A. (1993b) Prosodic morphology l: constraint interaction and satisfaction, Ms, University of Massachusetts, Amherst \& Rutgers University.

Mehrotra, R. C. (1965) "Stress in Hindi", Indian Linguistics, 26, 96-105.

Mohanan, K. P. (1979) Stress in Malayalam, Hindi, and Gujarati, Unpublished ms.

PANDEY, P. K. (1989) “Word accentuation in Hindi”, Lingua, 77, 37-73.

Pierrehumbert, J. B. \& R. NAIR (1996) "Implications of Hindi Prosodic Structure", Current Trends in Phonology: Models and Methods, 2, 549-584.

PRINCE, A. \& P. SMOLENSKY (1993) Optimality theory: Constraint interaction in generative grammar, Unpublished manuscript, Rutgers University, New Brunswick and the University of Colorado, Boulder. 
Dialectologia 25 (2020), 115-139.

ISSN: 2013-2247

RoY, S. (2017) "A Systematic Review of Hindi Prosody", New Delhi: Centre for Linguistics. Jawaharial Nehru University <https://www. researchgate.net/publication/315458696>.

StANTON, J. \& S. ZUKOFF (2015) "Prosodic effects of segmental correspondence", Proceedings of Chicago Linguistic Society, 51, 1, 501-515.

WALKER, R. (1997) Mongolian Stress, Licensing, and Factorial Typology, Ms., University of California, Santa Cruz.

Zukoff, S. (2012) The Phonology of Verbal Reduplication in Ancient Greek: An Optimality Theory Approach, Master's thesis, University of Georgia.

ZUKOFF, S. (2015) "Stress Restricts Reduplication", in Adam Albright \& Michelle Fullwood, Supplemental Proceedings of the Annual Meetings on Phonology 2014, Washington, DC: Linguistic Society of America. 